\title{
Structure Determination of Neoefrapeptins A to N: Peptides with Insecticidal Activity Produced by the Fungus Geotrichum candidum
}

\author{
Andreas Fredenhagen ${ }^{\dagger}$, Louis-Pierre Molleyres, Bettina Böhlendorf, Grit Laue
}

Received: December 9, 2005 / Accepted: May 9, 2006

(C) Japan Antibiotics Research Association

\begin{abstract}
The structures of neoefrapeptins A to N, peptides with insecticidal activity, were elucidated. They showed a close similarity to efrapeptin. However, all neoefrapeptins contained the very rare amino acid 1-aminocyclopropane-carboxylic acid and some of them also contained $(2 S, 3 S)-3$-methylproline. The neoefrapeptins are the first case, in which these amino acids are found as building blocks for linear peptides. They were identified by comparison of the silylated hydrolyzate to reference material by GC/MS (EI-mode). The sequence was elucidated using mass spectrometry (ESI+ mode). Full scan spectra showed two fragments in high yield, even under mild ionization conditions. MS/MS spectra of these two fragments yielded fragment rich spectra from which the sequence of the compounds was determined almost completely. The proteolytic cleavage with the proteinase papain yielded products that allowed to prove the rest of the sequence and the identity of the $C$-terminus to efrapeptin. The proteolytic cleavage products allowed furthermore to determine the position of the isobaric amino acids, pipecolic acid and 3-methylproline in neoefrapeptin $\mathrm{F}$, as well as the location of $R$-isovaline and $S$-isovaline. Papain digestion was such established as a tool for structure elucidation of peptides rich in $\alpha, \alpha$-dialkylated amino acids. CD spectra suggested a $3_{10}$ helical structure for neoefrapeptins $\mathrm{A}$ and $\mathrm{F}$.
\end{abstract}

Keywords efrapeptin, MS/MS, papain digestion, circular dichroism

\section{Introduction}

Natural products are a continuous and proven source of new lead compounds for the agrochemical industry. In a discovery program aimed at the identification of insecticides, several peptides were isolated from the strain SID 22780, isolated by CNPR (Center for Natural Products Research) in Singapore in 1997, and identified by DSMZ (Deutsche Sammlung von Mikroorganismen und Zellkulturen, Braunschweig, Germany) as Geotrichum candidum Link:F [1]. They were called neoefrapeptins A through to $\mathrm{N}$ where the annotation of the compounds $\mathrm{A}$ to $\mathrm{N}$ reflects solely the process of the discovery. In the patent application [1] the fermentation, isolation and biological activity of the neoefrapeptins was described. Having a positive charge they were isolated as acetate salts. In this paper the structures and physico-chemical properties of the newly discovered neoefrapeptins, which show a close sequence similarity to the efrapeptins [2 5] are presented.

Efrapeptins are a mixture of peptide antibiotics produced by the fungus Tolypocladium niveum. They are rich in pipecolic acid (Pip) and $\alpha, \alpha$-dialkylated amino acids like 1 -amino-isobutyric acid (Aib), which are quite rare as building blocks in peptides. They differ from peptaibols that are also rich in Aib by having a quite unique heterocyclic ring-system with a positive charge on the $C$ terminus. Efrapeptins have a strong insecticidal activity against chewing pests and mites [6]. They are inhibitors of
A. Fredenhagen (Corresponding author), G. Laue, B. Böhlendorf: Syngenta Crop Protection, Research, CPR Analytics, 4002 Basel, Switzerland, E-mail: andreas.fredenhagen@novartis.com
L.-P. Molleyres: Syngenta Crop Protection, Research Chemistry, 4002 Basel, Switzerland

${ }^{\dagger}$ Present address: Novartis Institutes for BioMedical Research, WKL-121.2.00, 4002 Basel, Switzerland 
the mitochondrial ATPase [7, 8]. Efrapeptin E was isolated for comparison from a strain Tolypocladium inflatum $\mathrm{W}$. Gams and was identical to the reported compound in all respects (amino acid composition, MS, MS/MS, biological activity).

\section{Results and Discussion}

\section{Structure of Neoefrapeptin A}

In order to determine the sequence of neoefrapeptin A (1) and to elucidate the structure amino acid analysis, MS and MS/MS experiments and selective digestion experiments were performed.

Amino acid analysis of the acidic hydrolyzate revealed the following components: S-Leu, Gly, Aib (1-aminoisobutyric acid), $\beta$-Ala ( $\beta$-alanine), both $S$-Iva (isovaline) and $R$-Iva, $S$-Pip (pipecolic acid), and an unknown amino acid. Interestingly, neoefrapeptin A contained one Iva in the $R$-configuration, while efrapeptin is known to contain only $S$-Iva. $R$-Iva is, however, quite common in fungal peptaibols [9].

MS and MS/MS experiments (see below) gave a molecular mass of $101 \mathrm{Da}$ for the unknown amino acid. This was $2 \mathrm{Da}$ less than Aib, suggesting either a cyclic or an unsaturated amino acid. The identification of the unknown amino acid was performed by derivatizing the hydrolyzate of neoefrapeptin A with $N$-Methyl$N$-trimethylsilyl-trifluoroacetamide (MSTFA) and dansyl chloride, respectively. The product mixtures were subsequently analyzed by GC/MS (EI(+) mode) and LC/MS $(\operatorname{ESI}(+)$ mode). The chromatographic peak of the unknown amino acid in GC/MS and LC/MS runs could be readily identified based on the known mass. Commercially available reference compounds were then compared to the neoefrapeptin A hydrolyzate (see Table 1) by GC-MS. Only 1-amino-cyclopropane-carboxylic acid (Acc) showed the same retention time and a very similar EI-MS. This finding was corroborated unambiguously by LC-NMR analysis of the chromatographic peak assigned to the unknown amino acid in the dansylated neoefrapeptin A hydrolyzate.

Acc is a very rare amino acid among natural products. It is a building block of BZR-Cotoxin II [10], a depsipeptide metabolite of a plant pathogen, antibiotic CBS 154-94A [11], a depsipeptide protein farnesyl transferase inhibitor, and of cytotrienins [12], ansamycin type antibiotics.

As shown below neoefrapeptin A carries an internal charge at the $C$-terminus. Consequently, the mass spectra $\left(\mathrm{ESI}(+)\right.$ mode) showed the $(\mathrm{M}+\mathrm{H})^{2+}$ rather than the $(\mathrm{M}+2 \mathrm{H})^{2+}$ molecular ion. Interestingly, two fragments at $\mathrm{m} / \mathrm{z} 943.6$ and 689.5 were observed - even at relatively low cone voltages $(20 \mathrm{~V}$; Fig. 1). Both, efrapeptins and

Table 1 Retention time and similarity index of the unknown amino acids as TMS derivatives with several reference compounds

\begin{tabular}{|c|c|c|c|}
\hline \multirow{2}{*}{$\begin{array}{l}\text { El-MS } \\
m / z\left(\mathrm{M}^{+}\right)\end{array}$} & \multirow{2}{*}{$\begin{array}{l}\text { RT (GC/MS) } \\
\text { (minute) }\end{array}$} & \multicolumn{2}{|c|}{$\begin{array}{c}\text { Similarity Index }{ }^{\text {a) }} \\
\text { (El-MS of TMS derivative) }\end{array}$} \\
\hline & & 245 & 273 \\
\hline Unknown amino acid in hydrolyzate of $\mathbf{1}$ & 7.40 & & b) \\
\hline Azetidine-2-carboxylic acid & 8.19 & & 676 \\
\hline 2-Amino-3-butenoic acid & 6.40 & & 662 \\
\hline Acc & 7.41 & & 934 \\
\hline Unknown amino acid in hydrolyzate of $\mathbf{7}$ & 9.63 & b) & \\
\hline Pip & 10.99 & 835 & \\
\hline 3-Piperidinecarboxylic acid & 12.44 & 259 & \\
\hline 4-Piperidinecarboxylic acid & 13.29 & 281 & \\
\hline 2-Methylproline & 10.00 & 837 & \\
\hline (2S,3S)-3-Methylproline & 9.62 & 836 & \\
\hline rac-(2R,3S)-3-Methylproline & 10.60 & 838 & \\
\hline rac-4-Methylproline & 10.10/10.31 & $844 / 845$ & \\
\hline N-Methylproline & 7.37 & 21 & \\
\hline
\end{tabular}

a) Forward similarity index calculation as implemented in Mass Lynx 3.5 [30]. Identical spectra would give a match of 999. From our experience values above 800 usually can be considered as similar spectra. Besides the similarity index values that consider intensities at a given mass, spectra were also evaluated manually with the same result.

b) Reference spectrum for similarity calculation. 
neoefrapeptins showed this quite unique feature of fragmenting easily into two parts. The larger fragment corresponded to the acetylated $N$-terminus (amino acids 1



Fig. 1 HR-MS of neoefrapeptin A. to 10 ) and the smaller to the $C$-terminus (residues 11 to 15), respectively. Examination of the sequence revealed no obvious indication why the breakage of the peptide bond between amino acid $\mathrm{Aib}^{10}$ and $\mathrm{Pip}^{11}$ is preferred over all others. Neoefrapeptin A also has a second Aib-Pip bond after residue 2, which showed no tendency to fragment. Adenopeptin, a tridecapeptide with the same $C$-terminus, also fragments at the only Aib-Pip bond of that molecule which is closer to the $C$-terminus (between amino acid 11 and 12) $[13,14]$. Apart from bond stability, the position of the internal positive charge along the $3_{10}$ helical structure (see CD studies, below) could be responsible for this preferred cleavage site.

The sequence of neoefrapeptin A could be fully elucidated by interpretation of the MS/MS spectra of the two fragments (Scheme 1). The MS/MS spectrum of the $C$ terminus (selected fragmentation mass $689.5 \mathrm{Da}$; Fig. 2) was identical to efrapeptin E, establishing the same partial sequence. Both, $y$ - and b-fragments were observed as indicated in Fig. 2. The mass of the $N$-terminal fragment was $943.7 \mathrm{Da}$ and $2 \mathrm{Da}$ lower than efrapeptin $\mathrm{E}$. Interpretation of the MS/MS fragmentation pattern (Fig. 3) and comparison with the one from efrapeptin E (Fig. 4)

Scheme 1 Structures of neoefrapeptins A to N

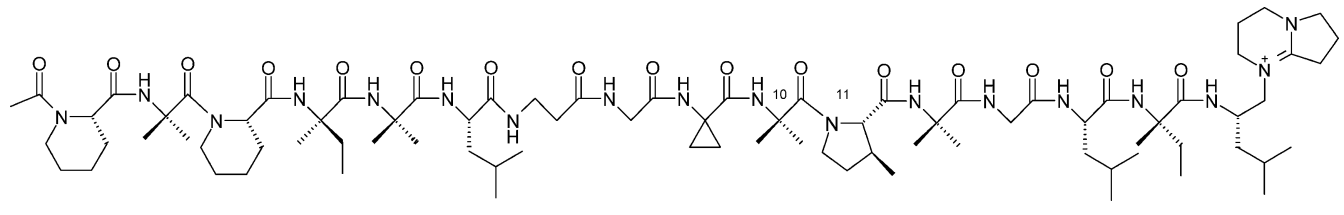

\begin{tabular}{|c|c|c|c|c|c|c|c|c|c|c|c|c|c|c|c|c|c|c|}
\hline & Residue \# & & 1 & 2 & 3 & 4 & 5 & 6 & 7 & 8 & 9 & 10 & 11 & 12 & 13 & 14 & 15 & \\
\hline 1 & Neoefrapeptin A & $A c$ & Pip & Aib & Pip & Iva & Aib & Leu & $\beta$-Ala & Gly & Acc & Aib & Pip & Aib & Gly & Leu & Iva & X \\
\hline 2 & Neoefrapeptin B & $A c$ & Pip & Aib & Pip & Iva & Iva & Leu & $\beta$-Ala & Gly & Acc & Aib & Pip & Aib & Gly & Leu & Iva & $X$ \\
\hline 3 & Neoefrapeptin C & Ac & Pip & Aib & Pip & Iva & Aib & Leu & $\beta$-Ala & Gly & Acc & Iva & Pip & Aib & Gly & Leu & Iva & $X$ \\
\hline 4 & Neoefrapeptin E & $A c$ & Pip & Aib & Pip & Iva & Iva & Leu & $\beta$-Ala & Gly & Acc & Iva & Pip & Aib & Gly & Leu & Iva & $x$ \\
\hline 5 & Neoefrapeptin D & $\mathrm{Ac}$ & Pip & Aib & Pip & Aib & Aib & Leu & $\beta$-Ala & Gly & Acc & Aib & Pip & Aib & Gly & Leu & Iva & $X$ \\
\hline 6 & Neoefrapeptin N & $A c$ & Pip & Aib & Pip & Aib & Aib & Leu & $\beta$-Ala & Gly & Acc & Aib & Pip & Aib & Gly & Leu & Aib & $x$ \\
\hline 7 & Neoefrapeptin F & Ac & Pip & Aib & Pip & Iva & Aib & Leu & $\beta$-Ala & Gly & Acc & Aib & 3M-Pro & Aib & Gly & Leu & Iva & $x$ \\
\hline 8 & Neoefrapeptin I & $A c$ & Pip & Aib & Pip & Iva & Iva & Leu & $\beta$-Ala & Gly & Acc & Aib & 3M-Pro & Aib & Gly & Leu & Iva & $X$ \\
\hline 9 & Neoefrapeptin M & $A c$ & Pip & Aib & Pip & Iva & Aib & Leu & $\beta$-Ala & Gly & Acc & Iva & 3M-Pro & Aib & Gly & Leu & Iva & $X$ \\
\hline 10 & Neoefrapeptin L & $A c$ & Pip & Aib & Pip & Iva & Iva & Leu & $\beta$-Ala & Gly & Acc & Iva & 3M-Pro & Aib & Gly & Leu & Iva & X \\
\hline 11 & Neoefrapeptin G & Ac & Pip & Aib & Pip & Iva & Aib & Leu & $\beta$-Ala & Gly & Acc & Aib & Pip & Aib & Gly & & & \\
\hline 12 & Neoefrapeptin H & Ac & Pip & Aib & Pip & Iva & Iva & Leu & $\beta$-Ala & Gly & Acc & Aib & Pip & Aib & Gly & & & \\
\hline & Efrapeptin E & $A c$ & Pip & Aib & Pip & S-Iva & Aib & Leu & $\beta$-Ala & Gly & Aib & Aib & Pip & Aib & Gly & Leu & Iva & $X$ \\
\hline
\end{tabular}

The drawn structure represents neoefrapeptin F. The bold line between amino acid 10 and 11 indicates the fragmentation observed in ESI-MS. Acc: 1-amino-cyclopropane-carboxylic acid, Aib: 1-Amino-isobutyric acid, $\beta$-Ala: 3-amino-propionic acid, 3M-Pro: 3-methylproline, Iva: isovaline, Pip: pipecolic acid. X represents the $C$-terminus with the 2,3,4,6,7,8-hexahydro-1-pyrrole[1,2- $\alpha$ ]pyrimidine. 


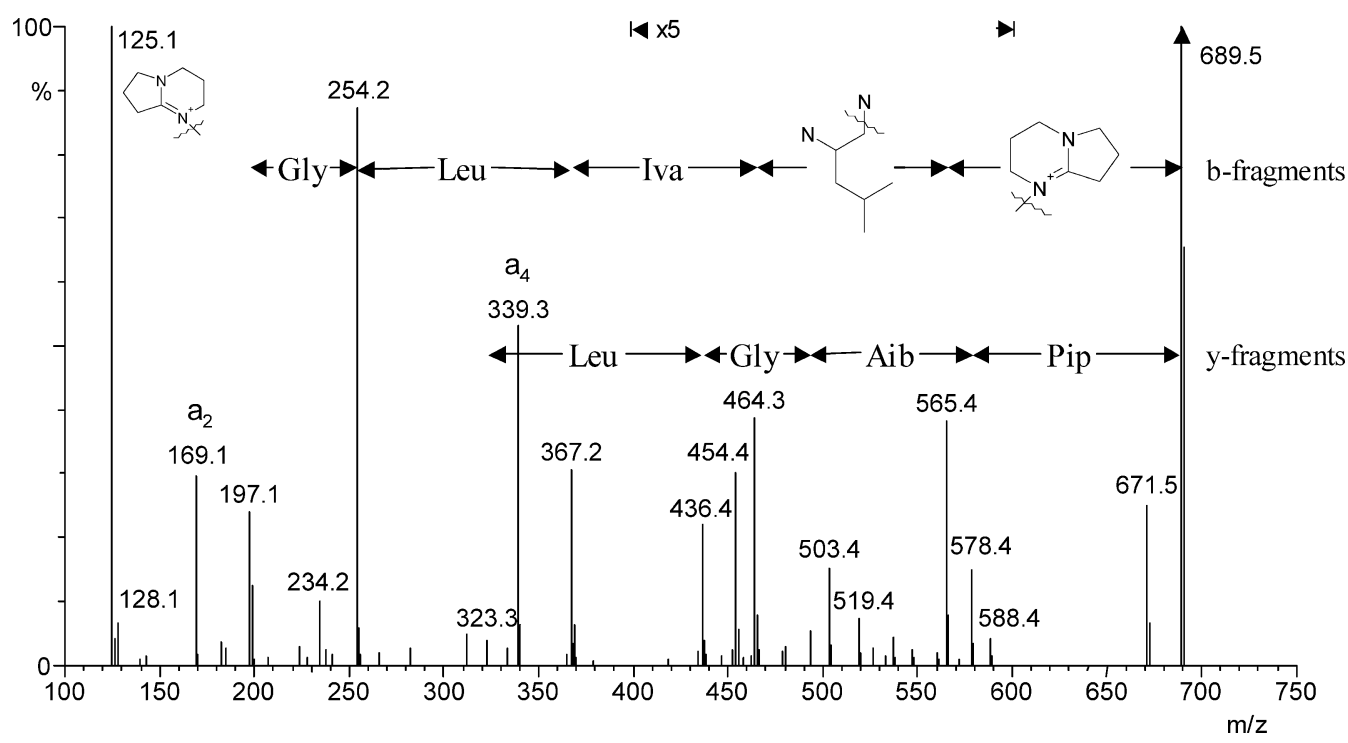

Fig. 2 MS/MS spectrum of fragment 689.6 of neoefrapeptin A (identical to efrapeptin E). The a-fragments $\left(a_{2}, a_{4}\right)$ are formed by the loss of $\mathrm{CO}(-28)$ from the corresponding b-fragments.



Fig. $3 \mathrm{MS} / \mathrm{MS}$ spectrum of fragment 943.7 of neoefrapeptin A (magnified by a factor of 2).

clearly revealed that Acc is at position 9 instead of Aib in efrapeptin E. The complete b-fragment series can be assigned to the proposed sequence, although the cleavage between $\beta$-alanine and glycine gave rise to a signal with low intensity. The intense fragments at masses 296.3, 409.3, 620.4, and 705.4 can be assigned to the partial yseries sequence Pip $^{3}$-Iva-Aib-Leu- $\beta$-Ala-Gly-Acc-Aib ${ }^{10}$ (Fig. 3). This finding was supported by collision induced dissociation of ion 705.5 $\mathrm{Da}$, which fragmented into the above mentioned masses. The HR-MS of the $(\mathrm{M}+\mathrm{H})^{2+}$ and of the two fragments 943.7 and 689.5 corroborated the proposed sequence.

To complete the structure elucidation of 1 cleaved fragments of this peptide were needed. Several proteinases were screened by LC-MS. Papain, a non-specific thiol protease [15 17] was found to digest neoefrapeptin A selectively. For an efficient reaction higher concentrations of EDTA and mercaptoethanol than that recommended by Allen were utilized [16]. Several fragments were observed by LC-MS analysis after prolonged exposure. The sequences of the products were established by HR-MS and MS/MS data (Scheme 2). Therefore, papain cleaves 


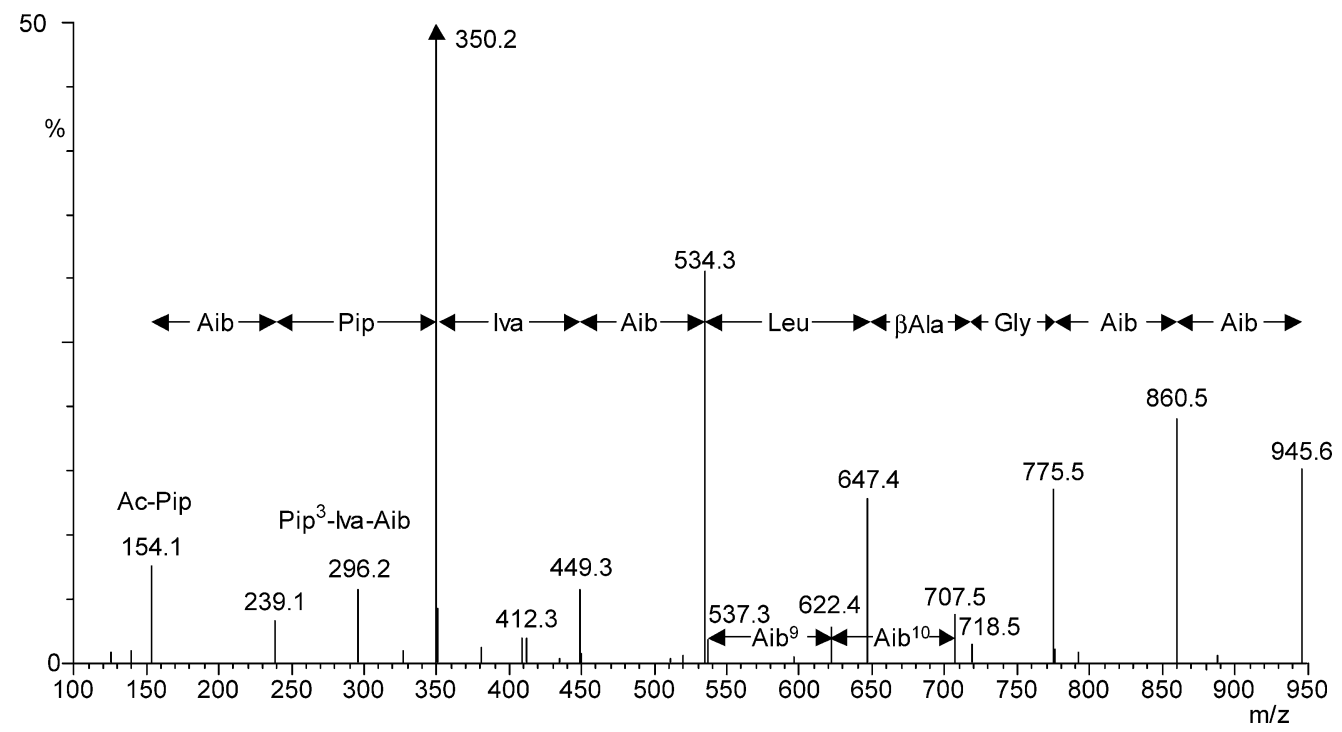

Fig. 4 MS/MS spectrum of fragment 945.7 of efrapeptin $E$ (magnified by a factor of 2).

Scheme 2 Proteolytic cleavage of neoefrapeptin A (1) by papain

Ac-Pip-Aib-Pip-Iva-Aib-Leu-ß-Ala-Gly-Acc-Aib-Pip-Aib-Gly-Leu-Iva-X

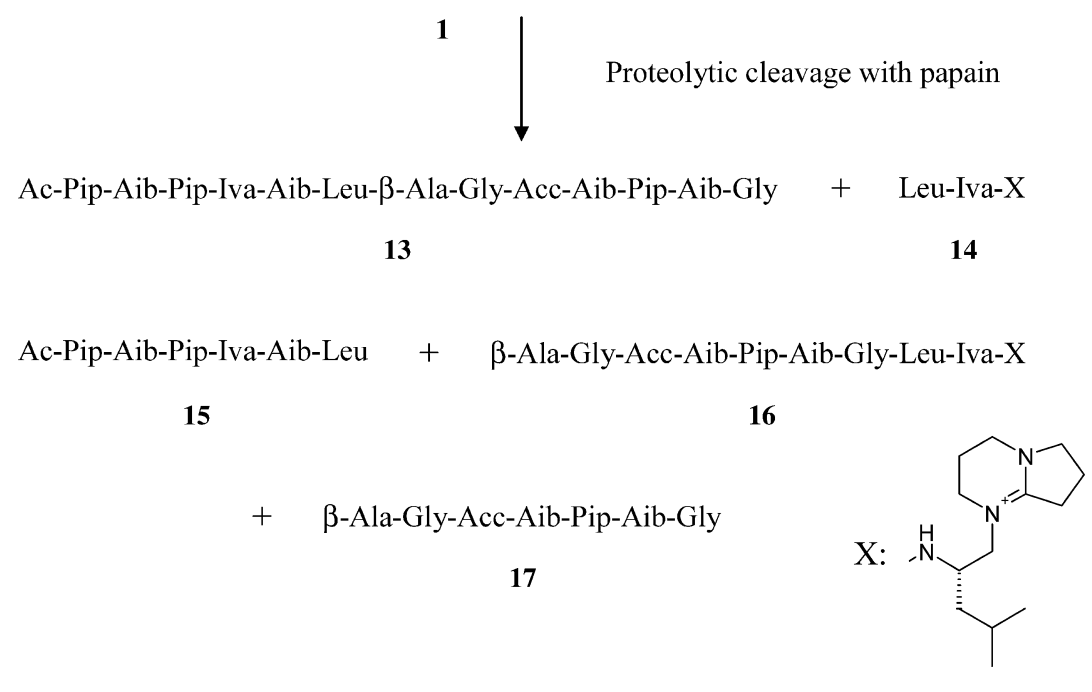

X represents the $C$-terminus with the 2,3,4,6,7,8-hexahydro-1-pyrrole[1,2- $\alpha$ ]pyrimidine.

neoefrapeptin A between $\mathrm{Gly}^{13}$ and Leu ${ }^{14}$ and, a bit slower, between $\mathrm{Leu}^{6}$ and $\beta$-Ala ${ }^{7}$. Gupta et al. obtained the identical $C$-terminal dipeptide $\mathbf{1 4}$ in low yield after partial acidic hydrolysis [4] of efrapeptin E. The ${ }^{13} \mathrm{C}$ NMR spectrum of the cleavage product 14 in $\mathrm{CD}_{3} \mathrm{OD}$ was identical to the one reported by Gupta et al. clarifying the structure of the $C$-terminus. However, the ESI-MS/MS fragmentation pattern (see experimental part) was completely different to the one reported by Gupta et al. using FAB-MS. The ESI-MS/MS spectrum can be explained by the proposed fragmentation mechanism
(Scheme 4) which was supported by accurate mass measurements and by $\mathrm{MS} / \mathrm{MS} / \mathrm{MS}\left(\mathrm{MS}^{3}\right)$ data. After cleavage of the bicyclus $(\mathrm{m} / \mathrm{z} 125)$ the positive charge gives rise to various reactions mostly without opening the peptide bonds.

Chiral amino acid analysis of the hydrolyzate by GC-MS of the cleavage products $\mathbf{1 4}$ and $\mathbf{1 5}$ clarified that compound 15 contained only $R$-Iva, while compound $\mathbf{1 4}$ contained only $S$-Iva. Thus $R$-Iva was incorporated in position 4 and $S$-Iva in position 15 of neoefrapeptin A. Hydrolysis of uncleaved neoefrapeptin A yielded less $S$-Iva than expected, 
Scheme 3 Proteolytic cleavage of neoefrapeptins by papain

Ac-Pip-Aib-Pip-Iva-W-Leu- $\beta$-Ala-Gly-Acc-Y-Z-Aib-Gly-Leu-Iva-X

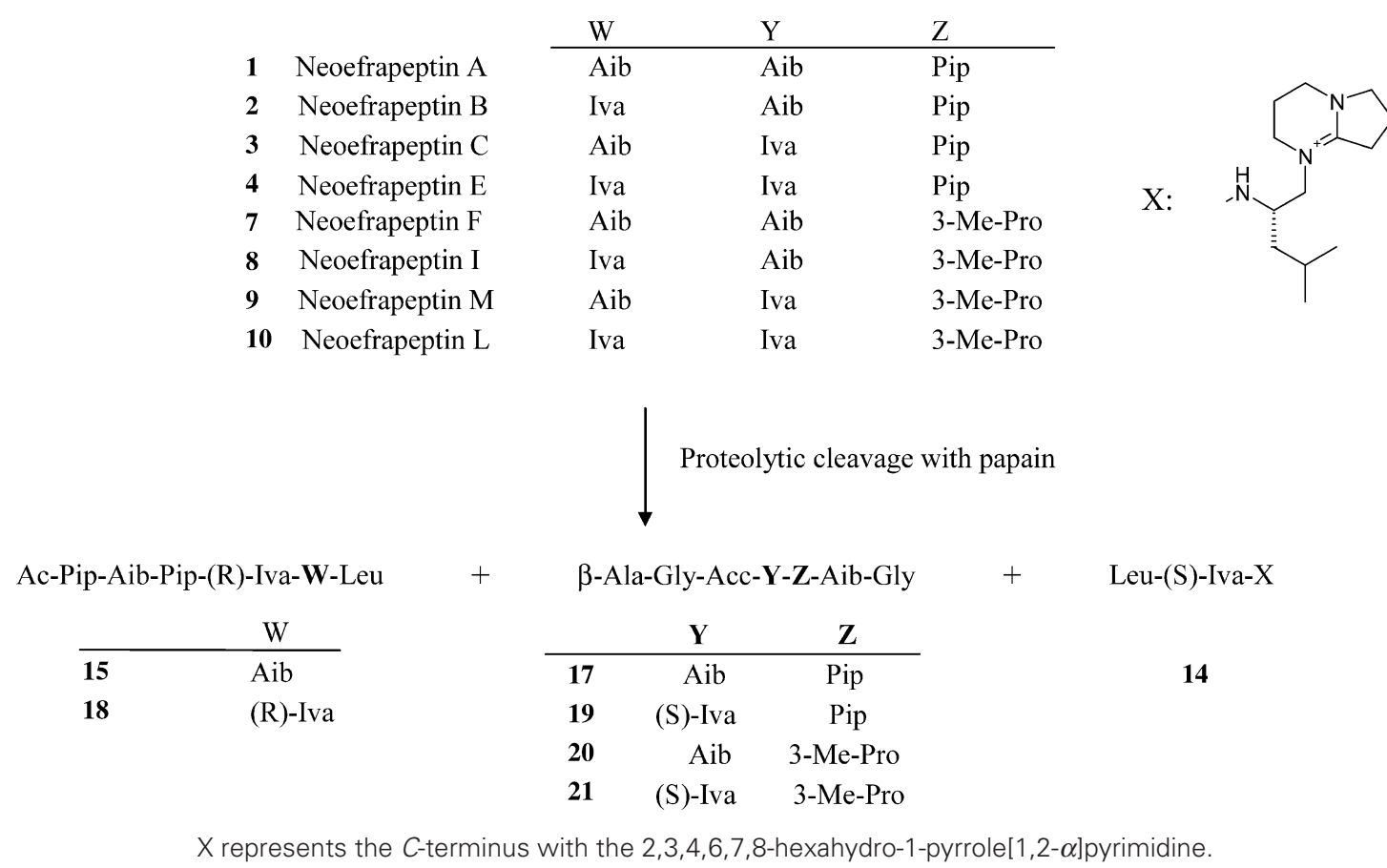

Scheme 4 Proposed ESI-MS/MS fragmentation mechanism of the dipeptide $\mathbf{1 4}$ obtained by cleavage of neoefrapeptin A by papain

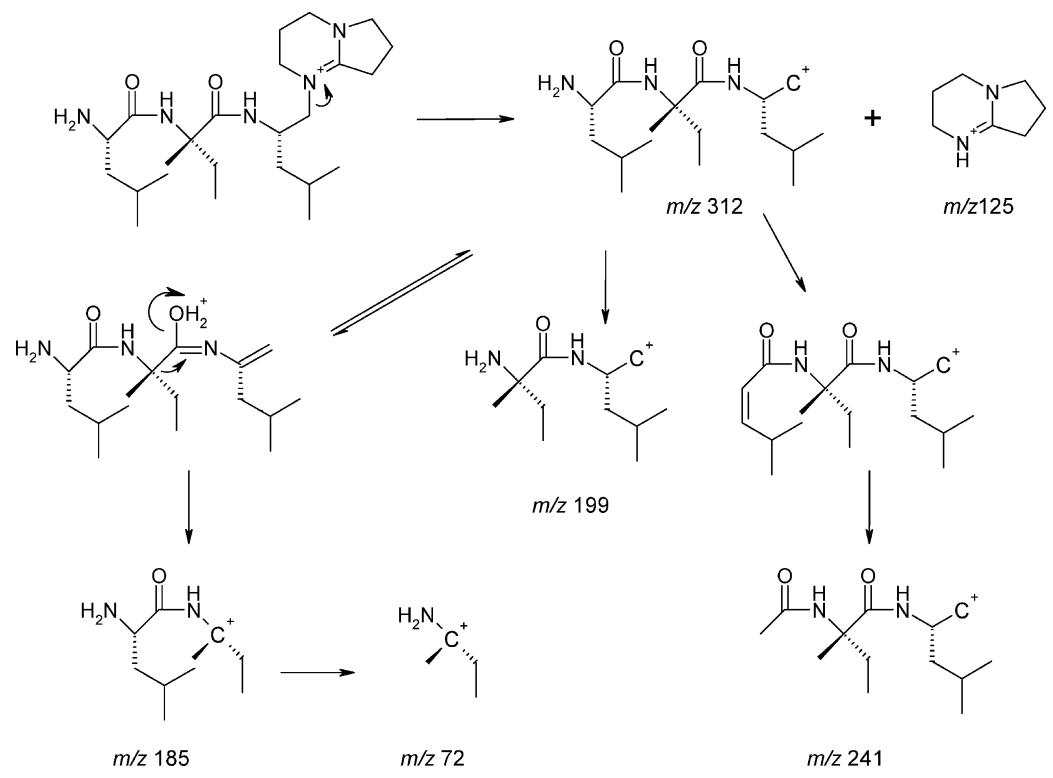

probably because the hydrolysis of the $C$-terminal amide bond was decelerated by the positive charge nearby.

To the best of our knowledge the use of papain or other proteases for cleavage of Aib-rich peptides or peptaibols has not been described previously. Interestingly, the inverse reaction also involving a Gly-Leu bond has been described by Slomczynska et al. [18]: In their synthesis of the peptaibol alamecthicin they coupled the $1 \sim 11$ segment having a $C$-terminal Gly and the $12 \sim 20$ segment, having a $N$-terminal Leu, using papain. Thus, depending on the 
experimental conditions, papain is capable to cleave or couple the Gly-Leu bond.

\section{Structures of Neoefrapeptins B, C and E}

The two compounds neoefrapeptin $\mathrm{B}$ and $\mathrm{C}(\mathbf{2}, \mathbf{3})$ were isolated as a homogenous peak having the same molecular mass. In a single experiment a very small amount of neoefrapeptin $\mathrm{C}$ was obtained and characterized by MS and MS/MS experiments. Amino acid analysis revealed one Aib less and one Iva more than neoefrapeptin A. The MS/MS spectrum of the $C$-terminus at $689.5 \mathrm{Da}$ was identical to that of neoefrapeptin A. The $N$-terminal fragment mass of $957.7 \mathrm{Da}$ was $14 \mathrm{Da}$ higher than neoefrapeptin A. Its MS/MS fragmentation pattern showed that the compound was a mixture: Several fragments with a difference of $14 \mathrm{Da}$ were observed in the range 534.4/548.3 Da to $858.6 / 872.5 \mathrm{Da}$. Thus, Aib and Iva must be interchanged in positions 5 and 10 in the two compounds. The major compound in this mixture was neoefrapeptin $\mathrm{B}$ with $\mathrm{Iva}^{5}$ and $\mathrm{Aib}^{10}$. The ratio of neoefrapeptin $\mathrm{B}$ to $\mathrm{C}$ was about $4: 1$ based on MS/MS.

Neoefrapeptin E (4) had a molecular weight of 1660 or $28 \mathrm{Da}$ higher than neoefrapeptin A. As with most neoefrapeptins, the MS/MS spectrum of the $C$-terminus was the same as in neoefrapeptin A. The MS/MS spectrum of the $\mathrm{N}$-terminal fragment revealed that Iva replaced two Aib residues at positions 5 and 10. So, compared to neoefrapeptin A, neoefrapeptin E combines the changes observed in neoefrapeptins B and C. It contains 4 Ivaresidues and only two Aib. As in the experiment described above, papain digestion products (Scheme 3 ) reveal that $\mathrm{Iva}^{4}$ and $\mathrm{Iva}^{5}$ are in the $R$-configuration, as peptides $\mathbf{1 5}$ and 18 contain only $R$-Iva. As papain digestion product 19 contains $S$-Iva, $\mathrm{Iva}^{10}$ in neoefrapetins $\mathrm{C}$ and $\mathrm{E}(\mathbf{3}, \mathbf{4})$ is in the $S$-configuration.

\section{Structure of Neoefrapeptin D}

HR-MS data of 5 suggested a mass difference of $14 \mathrm{Da}$ or a $\mathrm{CH}_{2}$-group less than neoefrapeptin A. Again, the MS/MS spectrum of the $C$-terminus was the same as in neoefrapeptin A. The $N$-terminal MS/MS spectrum showed masses of $14 \mathrm{Da}$ less in all fragments above $m / z 350$. Therefore amino acid 4 (Iva) in neoefrapeptin A was replaced by Aib in neoefrapeptin D.

\section{Structure of Neoefrapeptin $\mathbf{N}$}

Neoefrapeptin N (6) had a molecular weight of 1604 or $28 \mathrm{Da}$ lower than neoefrapeptin A. Neoefrapeptin $\mathrm{N}$ was the only compound among the neoefrapeptins with a different mass of the $C$-terminal MS fragment. The MS/MS spectrum revealed that the Iva at position 15 was replaced by Aib: All masses above $m / z 400$ are shifted by $14 \mathrm{Da}$. MS and MS/MS spectra of the $N$-terminal fragment were the same as of neoefrapeptin D. Neoefrapeptin $\mathrm{N}$ has the highest Aib content among the neoefrapeptins.

\section{Structure of Neoefrapeptin $F$}

Neoefrapeptin F eluted in the HPLC about 3 minutes later than neoefrapeptin A. HR-MS and MS/MS spectra of neoefrapeptin $\mathrm{F}$ were almost identical to neoefrapeptin A. Both compounds showed the same elemental composition. The MS/MS spectrum of the fragment 943.6 showed no difference to neoefrapeptin A, while in the MS/MS fragmentation pattern of the $C$-terminal fragment 689.6 of neoefrapeptin $\mathrm{F}$ the fragment at $\mathrm{m} / \mathrm{z} 578.4$ was missing. The molecular weights of the amino acids 11 and 12 were determined in the MS/MS experiments of the proteolytic cleavage product 20. It showed no difference to the MS/MS of $\mathbf{1 7}$ from neoefrapeptin A and therefore established Aib in position 12. Amino acid composition revealed that one Pip was replaced by a different amino acid with the same molecular weight. The retention times of a number of candidate molecules were compared as TMS derivatives by GC-MS (Table 1). Only (2S,3S)-3-methylproline (or $(2 R, 3 R)-3$-methylproline) eluted at the same RT as the unknown amino acid in the hydrolyzate of neoefrapeptin $\mathrm{F}$. The identification of 3-methylproline including the relative stereochemistry was corroborated unambiguously by LC-NMR analysis of the dansylated neoefrapeptin F hydrolyzate. The chirality was determined as $(2 S, 3 S)$ by GC/MS on a chiral capillary column by comparison with commercial and in-house available material.

Neoefrapeptin A has three Pip at positions 1, 3 and 11 and just one Pip is replaced by $(2 S, 3 S)-3$-methylproline in neoefrapeptin F. The proteolytic cleavage product 20 had no Pip left (Scheme 3). and it's amino acid composition clearly indicated that $(2 S, 3 S)$-3-methylproline was at position 11. Therefore, neoefrapeptin $F$ was identical to neoefrapeptin A with the exception that $S$-Pip at position 11 was substituted by $(2 S, 3 S)$-3-methylproline. As in neoefrapeptin $\mathrm{A}, \mathrm{Iva}^{4}$ was in the $R$-configuration and Iva ${ }^{15}$ in the $S$-configuration.

The amino acid 3-methylproline is extremely rare as a building block in natural products. It has been described as a building block of bottromycin $\mathrm{A}_{2}$ from Streptomyces bottropensis, scytalidamide $\mathrm{B}$, a cyclic heptapeptide from a marine fungus, roseotoxin $\mathrm{B}$ and roseocardin, two cyclodepsipeptides from the fungus Trichothecium roseum [19 23]. All these compounds contain 3-methylproline in the $(2 S, 3 S)$-form. It is interesting to observe, that all compounds mentioned above were isolated together with their proline derivative, whereas the neoefrapeptins 
were isolated together with Pip-containing analogues. Furthermore, the neoefrapeptins seem to be the first case, where 3-methylproline is described as a building block of linear peptides.

\section{Structures of Neoefrapeptins I, L and M}

The neoefrapeptins I, L and $\mathrm{M}$ all contained one $(2 S, 3 S)-3$ methylproline and only two Pip. Apart from that difference they had the same structures as neoefrapeptin B, C and E. Thus, apart from residue 11, neoefrapeptin I corresponded to neoefrapeptin $\mathrm{B}$, neoefrapeptin $\mathrm{L}$ to neoefrapeptin $\mathrm{E}$, and neoefrapeptin $M$ to neoefrapeptin $C$. Chiral amino acid analysis suggested $R$-Iva ${ }^{4}, R$-Iva ${ }^{5}, S$-Iva ${ }^{10}$ and $S$-Iva ${ }^{15}$.

\section{Structures of Neoefrapeptins $\mathbf{G}$ and $\mathbf{H}$}

The two peptides neoefrapeptins $\mathrm{G}$ and $\mathrm{H}$ were smaller than the others neoefrapeptins. In the HR-MS $(\mathrm{M}+\mathrm{H})^{+}$ ions of $\mathrm{m} / \mathrm{z} 1214.7151$ and 1228.7301 , were found. Additionally, fragments of $\mathrm{m} / \mathrm{z} 943$ or 957 were observed, suggesting that the $N$-terminus was identical to neoefrapeptin A or B/C. A small fragment corresponding to the loss of glycine was seen in the mass spectrum of neoefrapeptin $\mathrm{H}$. In the MS/MS spectrum of the $(\mathrm{M}+\mathrm{H})^{+}$ ion loss of Aib-Gly-OH from the $C$-terminus was detected and most of the sequence information could be deduced. The rest of the sequence information was observed in the MS/MS spectra of the fragment 943 and 957, respectively. Neoefrapeptin H differed from neoefrapeptin G by an Iva in position 5 instead of Aib. Analysis of the hydrolyzates showed that the compounds $\mathbf{1 1}$ and $\mathbf{1 2}$ contained only $10 \%$ of $(2 S, 3 S)$-3-methylproline and were therefore isolated in $90 \%$ purity. Iva was in the $R$-configuration. Neoefrapeptin $\mathrm{G}$ is identical to $\mathbf{1 3}$, formed by digestion of neoefrapeptin A with papain.

\section{Circular Dichroism Studies of Neoefrapeptins A and F}

Circular dichroism (CD) is a valuable tool for estimating the secondary structures of proteins and peptides. The $\mathrm{CD}$ spectra of neoefrapeptins $\mathrm{A}$ and $\mathrm{F}$ were recorded in water containing 5\% methanol (Fig. 5) and showed for both compounds a strong negative ellipticity at $204 \mathrm{~nm}$ and a minor one around $230 \mathrm{~nm}$. The negative $\mathrm{n}-\pi^{*}$ ellipticity around $230 \mathrm{~nm}$ of $\mathbf{1}$ and $\mathbf{7}$ was not observed in compound 13 (Scheme 2) and could therefore be due to a Cotton effect of the $C$-terminal chromophore. The spectra resembled the $\mathrm{CD}$ spectrum of a model compound for $3_{10}$-helix in water published recently by Formaggio et al. which showed a negative Cotton effect in the $201 \sim 206 \mathrm{~nm}$ region accompanied by a shoulder at approximately $222 \mathrm{~nm}$ [24]. The peptides are therefore not in an $\alpha$-helical conformation, which is very common among the Aib-rich

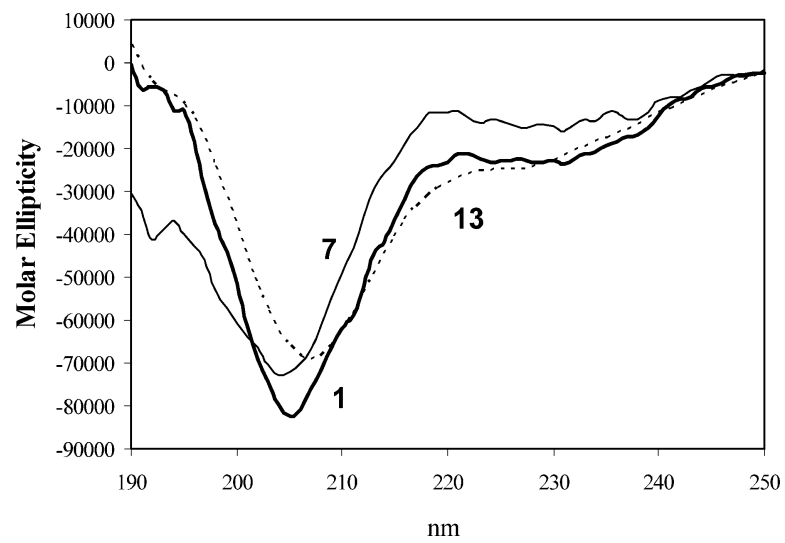

Fig. 5 CD spectra of neoefrapeptin A (-), neoefrapeptin $\mathrm{F}(-)$ and compound 13 (---- $)$.

peptaibols [25]. The results are consistent with the structural analysis of efrapeptin $\mathrm{C}$ by Huber and Sewald utilizing ${ }^{1} \mathrm{H}$ NMR. They suggested two $33_{10}$-helical regions at the $N$ terminus and between $\mathrm{Aib}^{9}$ to $\mathrm{Aib}^{15}$ which are linked by a flexible region between $\mathrm{Leu}^{6}$ and $\mathrm{Gly}^{8}{ }^{8}$ [26] In the crystal structure of efrapeptin $\mathrm{C}$, determined by Abrahams et al. in a complex with bovine $\mathrm{F}_{1}$-ATPase, the $N$-terminal part showed the typical $4 \rightarrow 1$ hydrogen bonds of a 3 -helix and was followed by a flexible region $\beta$-Ala ${ }^{7}-$ Gly $^{8}-$ Aib $^{9}$ [27]. The chirality of Iva was shown by Toniolo and Benedetti to induce no preference for right or left-handed helices and therefore the presence of the $R$ enationmer of Iva in $\mathbf{1}$ and $\mathbf{7}$ did not alter the direction of helical rotation [28].

The molar ellipticity $\theta$ at $204 \mathrm{~nm}$ is a bit weaker for neoefrapeptin $\mathrm{F}$ than for neoefrapeptin $\mathrm{A}$ and suggested that the $3_{10}$-helix is a bit less pronounced. The presence of 3-methylproline could induce a $\beta$-turn.

\section{Experimental}

\section{Chemicals}

Water for chromatography, TFA (BioChemica), acetonitrile (gradient grade), methanol (p.a.), acetyl chloride (puriss.), dansyl chloride (BioChemica), ethylenediaminetetraacetic acid disodium salt (EDTA; BioChemica) 2-mercaptoethanol (BioChemica), papain (\#76218, BioChemica) and Trishydrochloride (Trizma, BioChemica) were from Fluka, Buchs, Switzerland. MSTFA was from Pierce, Rockford, Ill. USA. 1-Amino-cyclopropane-carboxylic acid (Acc) and $R S$-Pip from Aldrich, St. Louis MO, USA. S-Pip and Aib were from Sigma, St. Louis MO, USA. Trifluoroacetic anhydride, $\beta$-alanine, $R S$-Leu, $R$-Iva, $S$-Iva and $(2 S, 3 S)$-3methylproline were from Acros Organics, Geel, Belgium. 
$S$-Leu was from Amresco, Solon OH, USA. The mixture of rac- $(2 R, 3 S)$-3-methylproline and rac-4-methylproline were from Syngenta Crop Protection's reference compounds collection.

HPLC analysis was performed on a Waters Alliance 2690 (Waters Corp. Milford, MA, USA) equipped with a Waters 996 diode array detector with the following experimental conditions. Column: YMC-Pak ODS-AQ $120 \AA, 5 \mu \mathrm{m}, 125 \times 2.0 \mathrm{~mm}$ plus precolumn $10 \mathrm{~mm}$; mobile phase A: water-TFA, $100: 0.1$; mobile phase B: acetonitrile - TFA, $100: 0.1$; flow: $0.5 \mathrm{ml} /$ minute; temp.: $40^{\circ} \mathrm{C}$; gradient: 0 minute $45 \% \mathrm{~B}, 10$ minutes $65 \% \mathrm{~B}, 12$ minutes $100 \% \mathrm{~B}$; injection: $5 \mu \mathrm{l}$ of a solution in methanol; UV-detection: $210 \mathrm{~nm}$. Retention times reported below refer to these conditions, unless stated.

Semipreparative HPLC separation was done on an Agilent 1100 with DAD detector. The flow was split $1: 20$ post column prior to MS analysis. A Quattro micro mass spectrometer (Waters) equipped with electrospray interface was used as a mass detector (cone $30 \mathrm{~V}$ ). Fractions were collected using a Gilson FC 204 fraction collector.

HR-MS and MS/MS spectra were recorded on a Q-TOF I (Micromass, Manchester UK) equipped with an electrospray source (ESI) as follows: source temp: $150^{\circ} \mathrm{C}$; desolvation temp.: $350^{\circ} \mathrm{C}$; mass range: 100 to $1000 \mathrm{Da}$ (100 1250 Da for 13 and 22). Cone voltage and collision energy are given below. A mixture of polypropylene glycol (PPG; Aldrich, average $\mathrm{M}_{\mathrm{n}} c a .425$ and 725 ; each $5 \mu \mathrm{g} / \mathrm{ml}$ ) in $0.02 \mathrm{M}$ ammonium acetate solution- ACN $1: 1$ was coinjected by a mixing $\mathrm{T}$ as a lock mass for accurate mass measurements to the MS at a flow rate of $0.2 \mathrm{ml} /$ minute. A $\left[\mathrm{M}+\mathrm{NH}_{4}\right]^{+}$ion of PPG close to the molecular ion was used for internal calibration. MS/MS experiments of neoefrapeptins $\mathrm{A}$ to $\mathrm{C}$ were done by direct infusion by pump syringe ( $5 \mu \mathrm{l} /$ minute) of a solution $c a .0 .05 \mathrm{mg} / \mathrm{ml}$ in $\mathrm{MeOH}-\mathrm{H}_{2} \mathrm{O}, 1: 1$. All HR-MS and MS/MS experiments of neoefrapeptins $\mathrm{D}$ to $\mathrm{N}$ were done by LC-MS with a Agilent 1100 (YMC-Pak ODS-AQ $120 \AA \AA, 5 \mu \mathrm{m}, 125 \times 2 \mathrm{~mm}$; mobile phase $\mathrm{A}: \mathrm{H}_{2} \mathrm{O}-\mathrm{HCOOH}, 99.5: 0.5$; mobile phase $\mathrm{B}$ : acetonitrile - $\mathrm{HCOOH}, 99.5: 0.5 ; 0.2 \mathrm{ml} /$ minute; gradient: 0 minute $5 \% \mathrm{~B}, 2$ minutes $5 \% \mathrm{~B}, 12$ minutes $95 \% \mathrm{~B}$; injection: $5 \mu$ l of a solution in methanol).

For $\mathbf{M S}^{3}$ and some MS/MS experiments, a LCQ deca XP plus (Thermo Finnigan, San Jose, CA, USA) equipped with an electrospray interface was used. In those experiments the instrument is mentioned. A sheath gas setting of 30 units and a spray voltage of $5 \mathrm{kV}$ was applied. The heated metal capillary was maintained at $250^{\circ} \mathrm{C}$. The system was optimized for $m / z 549[\mathrm{M}+\mathrm{H}]^{+}$of antimycin $\mathrm{A}_{1}$. Typical parameters are: Capillary voltage $20 \mathrm{~V}$; tube lens offset $-19 \mathrm{~V}$; entrance lens $-95 \mathrm{~V}$; mass range 120 to $1500 \mathrm{Da}$.
MS/MS parameters: Isolation width $3.8 \mathrm{Da}$; no wideband excitation; normalized collision energy $50 \%$; activation time $30 \mathrm{~ms}$.

GS/MS was done on Trace GC Ultra 2160 (Thermo Finnigan; split $1: 10$ ) with an MS Trace DSQ (Thermo Finnigan with EI-ionization in positive mode at $70 \mathrm{eV}$; emission current $+100 \mathrm{~mA}$; ion source temp.: $250^{\circ} \mathrm{C}$; scan range 50 650 amu) and an autosampler CombiPAL (CTC Analytics, Zwingen, Switzerland).

LC-NMR was done on an Inova $600 \mathrm{MHz}$ (Varian) and tube NMR on a Unity $500 \mathrm{MHz}$ (Varian).

CD measurements were made on a Jasco J710 (Japan Spectroscopic Co., Tokyo, Japan) using a quartz cell with a path length of $0.1 \mathrm{~cm}$. Each measurement was the average of three repeated scans in steps of $0.1 \mathrm{~nm}$ at ambient temperature and while the instrument was flushed with nitrogen. The compound concentration was $0.2 \mathrm{mM}$ in water with $5 \% \mathrm{MeOH}$. All spectra are background corrected. The optical rotation was determined with a Polarimeter 241 (Perkin-Elmer), FT-IR on a Spectrum One FT-IR (Perkin-Elmer) with universal ATR sampling accessory and UV on a Lamda 19 (Perkin-Elmer) with a cell length of $0.1 \mathrm{~cm}$ or on a UV 240 (Shimadzu) with a cell length of $1 \mathrm{~cm}$.

\section{Cleavage by the Protease Papain}

To $0.2 \mathrm{ml}$ of $0.05 \mathrm{M}$ Tris buffer, $\mathrm{pH} 6.8$, containing $20 \mathrm{mM}$ 2-mercaptoethanol and $0.5 \mathrm{mM}$ EDTA, $4 \mathrm{mg}$ papain $(9.8 \mathrm{units} / \mathrm{mg})$ and $1.4 \mathrm{mg}$ neoefrapeptin $\mathrm{A}$ in $10 \mu \mathrm{l}$ DMSO $-\mathrm{H}_{2} \mathrm{O} 1: 1$ were added. After 4 days at $37^{\circ} \mathrm{C}$ another portion of $2 \mathrm{mg}$ papain in $100 \mu \mathrm{l}$ buffer was added and the reaction was maintained for a total of 7 days. In the digest of neoefrapeptin A two new major peaks were observed by LC/MS at 6.3 minutes (14) and 9.7 minutes (13). Minor compounds were 15, 16 and 17.

HPLC conditions: Waters Alliance 2690 and Waters PDA 966; YMC-Pak ODS-AQ $120 \AA, 5 \mu \mathrm{m}, 125 \times 2.0 \mathrm{~mm}$ plus precolumn $10 \mathrm{~mm}$; solvent A: water-TFA $100: 0.01$; solvent B: acetonitrile - TFA $100: 0.01$; flow: $0.5 \mathrm{ml} /$ minute; oven temperature: $40^{\circ} \mathrm{C}$, gradient: $0 \% \mathrm{~B}$ to $100 \%$ B in 15 minutes.

By the same way papain digestion of neoefrapeptin B/C mixture was performed yielding compounds 14, 15, 17, 18 and 19, neoefrapeptin E yielded compounds 14, 18 and 19, neoefrapeptin F yielded 14, 15, 20, 22 and 23 , neoefrapeptin I yielded 14, 18 and 20, neoefrapeptin $M$ yielded 14, 15 and 21 and neoefrapeptin L yielded compounds 14, 18 and 21.

The desired peptide fragments were isolated by semipreparative HPLC with the following experimental conditions. Column: YMC-Pak ODS-AQ $120 \AA$, $5 \mu \mathrm{m}$, 
$125 \times 8.0 \mathrm{~mm}$; mobile phase A: water - TFA, $100: 0.1$; mobile phase B: acetonitrile - TFA, $100: 0.1$; flow: $3 \mathrm{ml} /$ minute; temp.: $30^{\circ} \mathrm{C}$; gradient: 0 minute $4 \% \mathrm{~B}, 10$ minutes $28 \% \mathrm{~B}$, 26 minutes $35 \%$ B, 43 minutes $60 \%$ B, 44 minutes $80 \%$ B; injection: $100 \mu \mathrm{l} ; 3$ injections per compound; UV-detection at $220 \mathrm{~nm}$; MS detection: $\mathrm{ESI}(+)$ cone $30 \mathrm{~V}, 200 \sim 1400 \mathrm{Da}$. The peaks with the correct $\mathrm{m} / \mathrm{z}$-values were collected with the fraction collector and the solvent was removed with a stream of nitrogen. Retention times (minutes): 17: 6.7; 20: 7.2; 19: 7.5; 21: 7.6; 14: 12.3; 16: 22.0; 23: 27.5; 15: 28.5; 18: $30.3 ; 13: 31.0 ; 22: 31.9$.

\section{Amino Acids Analysis by GC/MS}

The hydrolyzates of neoefrapeptins A to $\mathrm{N}(0.25 \mathrm{mg} ; 6 \mathrm{~N}$ $\mathrm{HCl}, 110^{\circ} \mathrm{C}, 24$ hours) were evaporated on the speedvac, dried over $\mathrm{P}_{2} \mathrm{O}_{5}$ for 24 hours and silylated with MSTFA $(50 \mu \mathrm{l})$ for 20 minutes at $90^{\circ} \mathrm{C}$. The TMS-derivatized amino acids were separated by capillary gas chromatography on a DB-35ms column (Restek, Bellefonte, PA, USA, $30 \mathrm{~m} \times$ $0.25 \mathrm{~mm} \times 0.25 \mu \mathrm{m}$ ) with an initial column temperature of $70^{\circ} \mathrm{C}$. The oven temperature was ramped at $5^{\circ} \mathrm{C} /$ minute to $170^{\circ} \mathrm{C}$ and then to $320^{\circ} \mathrm{C}$ at $20^{\circ} \mathrm{C} /$ minute (carrier gas: $\mathrm{He} ; 1.2 \mathrm{ml} /$ minute; injector temp. $240^{\circ} \mathrm{C}$; ion source temperature $250^{\circ} \mathrm{C}$ ). Compounds $15, \mathbf{1 7}, 18$ and 19 contained Pip, while compounds 20, 21, 22 and 23 contained (2S,3S)-3-methylproline.

EI-MS of di-TMS derivative of Acc: $245.0\left(\mathrm{M}^{+}, 7\right)$, 230.1 (12), 202.1 (36), 147.0 (77), 128.0 (39), 73.2 (100).

EI-MS of di-TMS derivative of $(2 S, 3 S)$-3-methylproline: $273\left(\mathrm{M}^{+}, 0.3\right), 258$ (1.3), 230 (4.9), 158 (3.8), 157 (14), 156 (100), 147 (4.6), 75 (2.4), 73 (18).

\section{Determination of the Chirality of the Amino Acids}

The hydrolyzates $\left(6 \mathrm{~N} \mathrm{HCl}, 24\right.$ hours at $\left.110^{\circ} \mathrm{C}\right)$ were esterified with 2-propanol $\left(1 \mathrm{ml}, 1\right.$ hour at $100^{\circ} \mathrm{C}$; acidified with $17 \%$ acetyl chloride $(\mathrm{v} / \mathrm{v})$; then dried under a stream of nitrogen) and then acetylated with trifluoroacetic anhydride $\left(0.2 \mathrm{ml}\right.$ and $1 \mathrm{ml} \mathrm{CH} \mathrm{Cl}_{2} ; 10$ minutes at $100^{\circ} \mathrm{C}$; then dried under a stream of nitrogen and redissolved in $0.25 \mathrm{ml} \mathrm{CH}_{2} \mathrm{Cl}_{2}$ ). The derivatized amino acids were resolved by capillary gas chromatography on a modified cyclodextrin stationary phase (Lipodex E, $50 \mathrm{~m} \times 0.25 \mathrm{~mm}$, Macherey-Nagel, Düren, Germany) [29] with an initial column temperature of $70^{\circ} \mathrm{C}$. The oven temperature was ramped at $5^{\circ} \mathrm{C} /$ minute to $150^{\circ} \mathrm{C}$, maintained $150^{\circ} \mathrm{C}$ for 5 minutes, then to $200^{\circ} \mathrm{C}$ at $10^{\circ} \mathrm{C} /$ minute (carrier gas: $\mathrm{He}$; $1 \mathrm{ml} /$ minute; injector temp. $180^{\circ} \mathrm{C}$; ion source temperature $200^{\circ} \mathrm{C}$ ). The usual amino acids were identified by comparison with commercial standards. The sample of rac$(2 R, 3 S)$-3-methylproline contained all four stereoisomers as minor by-products from synthesis and allowed therefore to prove that the column separates all four isomers: RT of $(2 S, 3 S) 16.39$ minutes; RT of $(2 R, 3 R) 16.75$ minutes; RT of $(2 R, 3 S)$ and $(2 S, 3 R): 17.64$ minutes and 18.15 minutes. The derivatized amino acids of neoefrapeptin $\mathrm{F}$ hydrolyzate showed a peak coeluting with commercially available (2S,3S)-3-methylproline.

Hydrolysis and GC-MS analysis of the TMS-derivatives on a chiral column revealed the chirality of Iva as follows: Compounds $\mathbf{1 5}$ and $\mathbf{1 8}$ contained only $R$-Iva (RT 10.28 minutes), while compounds 14,19 and 21 contained only $S$-Iva (RT 10.13 minutes).

\section{Dansyl Derivatives of the Hydrolyzate of Neoefrapeptins A or $\mathbf{F}$}

To the dried hydrolyzate of neoefrapeptin A or F $(0.25 \mathrm{mg}$; $6 \mathrm{~N} \mathrm{HCl}, 110^{\circ} \mathrm{C}, 24$ hours) in $100 \mu 1 \mathrm{H}_{2} \mathrm{O}$ a solution of $1 \mathrm{~N}$ $\mathrm{Na}_{2} \mathrm{CO}_{3}(10 \mu \mathrm{l})$ and dansyl chloride $(100 \mu \mathrm{l}, 13.5 \mathrm{mg}$ in $\mathrm{ACN}$ ) was added and kept in the dark for 1 hour at room temperature. Before HPLC analysis the reaction was acidified with TFA $(10 \% \mathrm{v} / \mathrm{v})$, the solvent removed by a stream of nitrogen and redissolved in acetonitrile.

${ }^{1} \mathrm{H}$ NMR of dansyl derivative of (2S,3S)-3-methylproline $\left(600 \mathrm{MHz} ; \mathrm{ACN}, \mathrm{D}_{2} \mathrm{O}, \mathrm{TFA}\right): \delta 8.91(1 \mathrm{H}, \mathrm{d}), 8.43(1 \mathrm{H}, \mathrm{d})$, $8.40(1 \mathrm{H}, \mathrm{d}), 8.04(1 \mathrm{H}, \mathrm{d}), 7.91(1 \mathrm{H}, \mathrm{t}), 7.88(1 \mathrm{H}, \mathrm{t}), 3.97$ $(1 \mathrm{H}, \mathrm{d}, J=4.9 \mathrm{~Hz}, \mathrm{H}-1), 3.47(1 \mathrm{H}, \mathrm{m}), 3.43(1 \mathrm{H}, \mathrm{m}), 3.41$ $(6 \mathrm{H}, \mathrm{s}), 2.41(1 \mathrm{H}, \mathrm{m}), \sim 2.13(1 \mathrm{H}, \mathrm{m}), 1.46(1 \mathrm{H}, \mathrm{m}), 0.90$ ( $3 \mathrm{H}, \mathrm{d}, J=6.6 \mathrm{~Hz}, 3-\mathrm{Me})$.

${ }^{1} \mathrm{H}$ NMR of dansyl derivative of rac- $(2 R, 3 S)-3$ methylproline (600 MHz; ACN, $\left.\mathrm{D}_{2} \mathrm{O}, \mathrm{TFA}\right): \delta 8.85(1 \mathrm{H}, \mathrm{d})$, $8.42(1 \mathrm{H}, \mathrm{d}), 8.32(1 \mathrm{H}, \mathrm{d}), 8.04(1 \mathrm{H}, \mathrm{d}), 7.90(1 \mathrm{H}, \mathrm{t})$, $7.87(1 \mathrm{H}, \mathrm{t}), 4.32(1 \mathrm{H}, \mathrm{d}, J=8.7 \mathrm{~Hz}, \mathrm{H}-1), 3.63(1 \mathrm{H}, \mathrm{t}$, $J=8.5 \mathrm{~Hz}), 3.40(6 \mathrm{H}, \mathrm{s}), 3.35(1 \mathrm{H}, \mathrm{q}, J=8.5 \mathrm{~Hz}), 2.49(1 \mathrm{H}$, $\mathrm{m}, \mathrm{H}-3), \sim 2.14(1 \mathrm{H}, \mathrm{m}), 1.74(1 \mathrm{H}, \mathrm{m}), 0.96(3 \mathrm{H}, \mathrm{d}$, $J=6.6 \mathrm{~Hz}, 3-\mathrm{Me})$.

\section{Physico-chemical Data}

Neoefrapeptin A

HPLC Rt: 6.7 minutes HR-MS (cone Voltage: 20 V) Found: 689.5029 Calcd for $\mathrm{C}_{36} \mathrm{H}_{65} \mathrm{~N}_{8} \mathrm{O}_{5}$ : 689.5078; Found: $816.5308(\mathrm{M}+\mathrm{H})^{2+}$ Calcd for $\mathrm{C}_{82} \mathrm{H}_{140} \mathrm{~N}_{18} \mathrm{O}_{16}: 816.5347$; Found: 943.5562 Calcd for $\mathrm{C}_{46} \mathrm{H}_{75} \mathrm{~N}_{10} \mathrm{O}_{11}$ : 943.5617. MS/MS of 943.6 (cone Voltage: $40 \mathrm{~V}$; collision energy: $40 \sim 50 \mathrm{~V})$ 943.6; 858.5; 705.5; 647.4; 620.5; 534.3; $449.4 ; 409.4 ; 350.3 ; 296.3 ; 239.1 ; 154.1$. MS/MS of 689.6 (cone Voltage: $100 \mathrm{~V}$; collision energy: $25 \sim 35 \mathrm{~V}$ ): 689.6 ; $671.6 ; 578.5 ; 565.5 ; 464.4 ; 436.4 ; 367.3 ; 339.3 ; 323.4$; $254.2 ; 197.2 ; 169.2 ; 125.1$. MS/MS of 705.1 (Quattro II, Micromass, cone Voltage: $80 \mathrm{~V}$; collision energy: $35 \mathrm{~V}$, resolution of MS2: 11): 705, 620, 409, 296, 211, 183, 84. $\mathrm{UV} \lambda_{\max }^{\mathrm{H}_{2} \mathrm{O} / \mathrm{MeOH}} 95: 5 \mathrm{~nm}(\varepsilon) 204$ (43,000), 230 (sh, 9,600). $[\alpha \mathrm{D}]_{\mathrm{D}}^{25}+0.1(c 0.1, \mathrm{MeOH})$. FT-IR $v_{\max }$ (film) $\mathrm{cm}^{-1} 3290$ 
(br), 2940, 2870, 1655 (C=O), 1540, 1440, 1420, 1390, $1260,1200,1170,1140$. $\mathrm{CD}$ (in $\mathrm{H}_{2} \mathrm{O} / \mathrm{MeOH} 95: 5$ ): see Fig. 5.

Neoefrapeptin B and Neoefrapeptin C Mixture HPLC Rt: 7.6 minutes (compounds are coeluting). HR-MS (cone Voltage: $20 \mathrm{~V}$ ) Found: 689.5005 Calcd for $\mathrm{C}_{36} \mathrm{H}_{65} \mathrm{~N}_{8} \mathrm{O}_{5}$ : 689.5078; Found: $823.5363(\mathrm{M}+\mathrm{H})^{2+}$ Calcd for $\mathrm{C}_{83} \mathrm{H}_{142} \mathrm{~N}_{18} \mathrm{O}_{16}$ : 823.5426; Found: 957.5687 Calcd for $\mathrm{C}_{47} \mathrm{H}_{77} \mathrm{~N}_{10} \mathrm{O}_{11}$ : 957.5773. MS/MS of 957.6 (cone Voltage: $40 \mathrm{~V}$; collision energy: $40 \sim 50 \mathrm{~V})$ : 957.6; 872.5; 858.6; $719.6 ; 661.6 ; 647.6 ; 634.5 ; 548.3 ; 534.4 ; 449.3 ; 350.3$; 310.3 ; 239.1; 154.1. MS/MS of 689.6 (cone Voltage: $100 \mathrm{~V}$; collision energy: $25 \sim 35 \mathrm{~V}$ ): 689.6 ; 671.6; 578.5; 565.5; $464.4 ; 436.4 ; 367.3 ; 339.3 ; 323.4 ; 254.2 ; 197.2 ; 169.2$; 125.1 .

\section{Neoefrapeptin C}

HR-MS (cone Voltage: $20 \mathrm{~V}$ ) Found: 689.5053 Calcd for $\mathrm{C}_{36} \mathrm{H}_{65} \mathrm{~N}_{8} \mathrm{O}_{5}$ : 689.5078; Found: $823.5427(\mathrm{M}+\mathrm{H})^{2+}$ Calcd for $\mathrm{C}_{83} \mathrm{H}_{142} \mathrm{~N}_{18} \mathrm{O}_{16}$ : 823.5426; Found: 957.5729 Calcd for $\mathrm{C}_{47} \mathrm{H}_{77} \mathrm{~N}_{10} \mathrm{O}_{11}$ : 957.5773. MS/MS of 957.6 (cone Voltage: $20 \mathrm{~V}$; collision energy: $30 \mathrm{~V}$ ): 957.6; 858.5; 775.5; 719.5; $647.4 ; 620.4 ; 534.3 ; 449.3 ; 350.2 ; 296.2 ; 239.1 ; 154.1$. MS/MS of 689.6 (cone Voltage: $20 \mathrm{~V}$; collision energy: $50 \mathrm{~V})$ : $689.5 ; 671.5 ; 578.4 ; 464.3 ; 454.3 ; 436.4 ; 367.2$; $339.2 ; 254.2 ; 197.1 ; 169.1 ; 125.1$.

\section{Neoefrapeptin D}

HPLC Rt: 6.2 minutes HR-MS (cone Voltage: $20 \mathrm{~V}$ ) Found: 689.5035 Calcd for $\mathrm{C}_{36} \mathrm{H}_{65} \mathrm{~N}_{8} \mathrm{O}_{5}$ : 689.5078; Found: $809.5253(\mathrm{M}+\mathrm{H})^{2+}$ Calcd for $\mathrm{C}_{81} \mathrm{H}_{138} \mathrm{~N}_{18} \mathrm{O}_{16}: 809.5269$; Found: 929.5430 Calcd for $\mathrm{C}_{45} \mathrm{H}_{73} \mathrm{~N}_{10} \mathrm{O}_{11}$ : 929.5460 . MS/MS of 929.6 (cone Voltage: $40 \mathrm{~V}$; collision energy: 30 45 V): 929.6; 844.5; 761.5; 704.5; 691.5; 633.4; 606.4; $520.3 ; 435.3 ; 395.3 ; 350.3 ; 282.2 ; 239.2 ; 154.1$. MS/MS of 689.5 (cone Voltage: $40 \mathrm{~V}$; collision energy: $45 \sim 60 \mathrm{~V}$ ): $689.5 ; 671.5 ; 578.4 ; 565.4 ; 464.4 ; 454.4 ; 436.4 ; 367.2$; $339.2 ; 254.1 ; 197.1 ; 169.1 ; 125.1$. UV $\lambda_{\max }^{\mathrm{H}_{2} \mathrm{O}} \mathrm{MeOH}^{25: 5} \mathrm{~nm}(\varepsilon)$ $<200(50,400)$. $[\alpha \mathrm{D}]_{\mathrm{D}}^{25}+0.3(c 0.1, \mathrm{MeOH})$.

\section{Neoefrapeptin E}

HPLC Rt: 8.2 minutes HR-MS (cone Voltage: $20 \mathrm{~V}$ ) Found: 689.5018 Calcd for $\mathrm{C}_{36} \mathrm{H}_{65} \mathrm{~N}_{8} \mathrm{O}_{5}$ : 689.5078; Found: $830.5455(\mathrm{M}+\mathrm{H})^{2+}$ Calcd for $\mathrm{C}_{84} \mathrm{H}_{144} \mathrm{~N}_{18} \mathrm{O}_{16}: 830.5504$; Found: 971.5896 Calcd for $\mathrm{C}_{48} \mathrm{H}_{79} \mathrm{~N}_{10} \mathrm{O}_{11}$ : 971.5930 . MS/MS of 971.6 (cone Voltage: $40 \mathrm{~V}$; collision energy: 30 45 V): 971.6; 872.5; 789.5; 733.5; 661.5; 634.4; 548.3; $449.3 ; 423.3 ; 350.2 ; 310.2 ; 239.1 ; 154.1$. MS/MS of 689.5 (cone Voltage: $40 \mathrm{~V}$; collision energy: $45 \sim 50 \mathrm{~V}$ ): 689.5 ; $671.5 ; 578.5 ; 565.4 ; 464.3 ; 454.3 ; 436.4 ; 367.2 ; 339.2$;
$323.3 ; 254.2 ; 197.1 ; 169.1 ; 125.1$. UV $\lambda_{\max }^{\mathrm{H}_{2} \mathrm{O}} \mathrm{MeOH} 95: 5 \mathrm{~nm}(\varepsilon)$ $<200(48,300) .[\alpha \mathrm{D}]_{\mathrm{D}}^{25}+0.3(c 0.1, \mathrm{MeOH})$. FT-IR $v_{\max }$ (film) $\mathrm{cm}^{-1} 3290$ (br), 2940, 2870, 1655 (C=O), 1540, 1460, 1440, 1390, 1260, 1170, 1140.

Neoefrapeptin F

HPLC Rt: 8.9 minutes HR-MS (cone Voltage: $20 \mathrm{~V}$ ) Found: 689.5058 Calcd for $\mathrm{C}_{36} \mathrm{H}_{65} \mathrm{~N}_{8} \mathrm{O}_{5}$ : 689.5078; Found: $816.5270(\mathrm{M}+\mathrm{H})^{2+}$ Calcd for $\mathrm{C}_{82} \mathrm{H}_{140} \mathrm{~N}_{18} \mathrm{O}_{16}: 816.5347$; Found: 943.5602 Calcd for $\mathrm{C}_{46} \mathrm{H}_{75} \mathrm{~N}_{10} \mathrm{O}_{11}$ : 943.5617 . MS/MS of 943.6 (cone Voltage: $40 \mathrm{~V}$; collision energy: 30 45 V) 943.6; 858.5; 775.5; 718.5; 705.4; 647.4; 620.4; 534.3 ; 449.3; 409.3; 350.2; 296.2; 239.1; 154.1. MS/MS of 689.5 (cone Voltage: $40 \mathrm{~V}$; collision energy: $45 \sim 50 \mathrm{~V}$ ): $689.5 ; 671.5 ; 565.4 ; 464.3 ; 436.4 ; 367.2 ; 339.3 ; 254.2$; $197.1 ; 169.1 ; 125.1$. UV $\lambda_{\max }^{\mathrm{H}_{2} \mathrm{O} / \mathrm{MeOH} 95: 5} \mathrm{~nm}(\varepsilon) 204(42,400)$, 230 (sh, 10,100). $[\alpha \mathrm{D}]_{\mathrm{D}}^{25}+0.2(c 0.1, \mathrm{MeOH})$. FT-IR $v_{\max }$ (film) $\mathrm{cm}^{-1} 3290$ (br), 2930, 2870, $1645(\mathrm{C}=\mathrm{O}), 1530$, $1440,1410,1390,1260,1170,1140$. CD (in $\mathrm{H}_{2} \mathrm{O} / \mathrm{MeOH}$ $95: 5)$ : see Fig. 5.

Neoefrapeptin G

HPLC Rt: 9.7 minutes (gradient as in cleavage with papain). HR-MS (cone Voltage: 20 V) Found: 1214.7151 $(\mathrm{M}+\mathrm{H})^{+}$Calcd for $\mathrm{C}_{58} \mathrm{H}_{96} \mathrm{~N}_{13} \mathrm{O}_{15}:$ 1214.7149; Found: 943.5634 Calcd for $\mathrm{C}_{46} \mathrm{H}_{75} \mathrm{~N}_{10} \mathrm{O}_{11}$ : 943.5617. MS/MS of 1214.7 (cone Voltage: $20 \mathrm{~V}$; collision energy: $40 \mathrm{~V}$ ): 1054.7, 943.6; 858.5; 647.4; 534.3; 449.3; 350.2; 154.1 . MS/MS of 943.6 (cone Voltage: $20 \mathrm{~V}$; collision energy: $30 \mathrm{~V})$ : 943.6; 858.5; 775.5; 718.4; 705.4; 647.4; 620.4; $534.3 ; 449.3 ; 410.3 ; 350.2 ; 296.2 ; 239.1 ; 154.1 .[\alpha \mathrm{D}]_{\mathrm{D}}^{25}$ -0.1 ( c 0.1, MeOH). Additional physico-chemical data see compound 13.

\section{Neoefrapeptin $\mathrm{H}$}

HPLC Rt: 9.9 minutes (gradient as in cleavage with papain). HR-MS (cone Voltage: 20 V) Found: 1228.7301 $(\mathrm{M}+\mathrm{H})^{+}$Calcd for $\mathrm{C}_{59} \mathrm{H}_{98} \mathrm{~N}_{13} \mathrm{O}_{15}: 1228.7305$; Found: 1153.6980 Calcd for $\mathrm{C}_{57} \mathrm{H}_{93} \mathrm{~N}_{12} \mathrm{O}_{13}$ : 1153.6985; Found: 957.5752 Calcd for $\mathrm{C}_{47} \mathrm{H}_{77} \mathrm{~N}_{10} \mathrm{O}_{11}$ : 957.5773. MS/MS of 1228.7 (cone Voltage: $20 \mathrm{~V}$; collision energy: $30 \mathrm{~V}$ ): 1068.7, 957.6; 872.5; 719.5, 661.4; 548.3; 449.3; 350.2; 154.1. MS/MS of 957.6 (cone Voltage: $20 \mathrm{~V}$; collision energy: $40 \mathrm{~V})$ : 957.6; 872.5; 789.5; 719.5; 661.4; 634.4; $548.3 ; 449.3 ; 423.3 ; 350.2 ; 310.2 ; 239.1 ; 154.1$.

\section{Neoefrapeptin I}

HPLC Rt: 9.7 minutes HR-MS (cone Voltage: $20 \mathrm{~V}$ ) Found: 689.4979 Calcd for $\mathrm{C}_{36} \mathrm{H}_{65} \mathrm{~N}_{8} \mathrm{O}_{5}$ : 689.5078; Found: $823.5396(\mathrm{M}+\mathrm{H})^{2+}$ Calcd for $\mathrm{C}_{83} \mathrm{H}_{142} \mathrm{~N}_{18} \mathrm{O}_{16}: 823.5426$; Found: 957.5628 Calcd for $\mathrm{C}_{47} \mathrm{H}_{77} \mathrm{~N}_{10} \mathrm{O}_{11}$ : 957.5773 . 
MS/MS of 957.6 (cone Voltage: $40 \mathrm{~V}$; collision energy: $30 \mathrm{~V})$ : 957.6; 872.5; 719.4; 661.4; 634.4; 548.3; 449.3; $350.2 ; 310.2 ; 239.1 ; 154.1$. MS/MS of 689.6 (cone Voltage: $40 \mathrm{~V}$; collision energy: $50 \mathrm{~V}): 689.5 ; 671.5 ; 565.4 ; 503.4$, $464.3 ; 436.4 ; 367.2 ; 339.2 ; 254.1 ; 197.1 ; 169.1 ; 125.1$. UV $\lambda_{\max }^{\mathrm{H}_{2} \mathrm{O} / \mathrm{MeOH}} 95: 5 \mathrm{~nm}(\varepsilon)<200(50,900) .[\alpha \mathrm{D}]_{\mathrm{D}}^{25}+0.3(c 0.1$, $\mathrm{MeOH})$.

\section{Neoefrapeptin L}

HPLC Rt: 10.3 minutes HR-MS (cone Voltage: $20 \mathrm{~V}$ ) Found: 689.5064 Calcd for $\mathrm{C}_{36} \mathrm{H}_{65} \mathrm{~N}_{8} \mathrm{O}_{5}$ : 689.5078 Found: $830.5529(\mathrm{M}+\mathrm{H})^{2+}$ Calcd for $\mathrm{C}_{84} \mathrm{H}_{144} \mathrm{~N}_{18} \mathrm{O}_{16}: 830.5504$; Found: 971.5920 Calcd for $\mathrm{C}_{48} \mathrm{H}_{79} \mathrm{~N}_{10} \mathrm{O}_{11}$ : 971.5930 . MS/MS of 971.6 (cone Voltage: $20 \mathrm{~V}$; collision energy: $30 \mathrm{~V}): 971.6 ; 872.5 ; 733.5 ; 661.4 ; 634.4 ; 548.4 ; 449.3$; $424.3 ; 350.2 ; 310.2 ; 239.1 ; 154.1$. MS/MS of 689.6 (cone Voltage: $20 \mathrm{~V}$; collision energy: $50 \mathrm{~V})$ : $689.6 ; 671.5 ; 436.4$; $339.2 ; 254.2 ; 197.1 ; 169.1 ; 125.1$. UV $\lambda_{\max }^{\mathrm{H}_{2} \mathrm{O} / \mathrm{MeOH} 95: 5} \mathrm{~nm}(\varepsilon)$ $<200(45,800)$. $[\alpha \mathrm{D}]_{\mathrm{D}}^{25}+0.2(c 0.1, \mathrm{MeOH})$.

\section{Neoefrapeptin M}

HPLC Rt: 9.4 minutes HR-MS (cone Voltage: $20 \mathrm{~V}$ ) Found: 689.5099 Calcd for $\mathrm{C}_{36} \mathrm{H}_{65} \mathrm{~N}_{8} \mathrm{O}_{5}$ : 689.5078 Found: $823.5443(\mathrm{M}+\mathrm{H})^{2+}$ Calcd for $\mathrm{C}_{83} \mathrm{H}_{142} \mathrm{~N}_{18} \mathrm{O}_{16}: 823.5426$; Found: 957.5807 Calcd for $\mathrm{C}_{47} \mathrm{H}_{77} \mathrm{~N}_{10} \mathrm{O}_{11}$ : 957.5773 . MS/MS of 957.6 (cone Voltage: $20 \mathrm{~V}$; collision energy: $30 \mathrm{~V})$ : 957.6; 858.5; 775.5, 719.5; 705.4, 647.4; 620.4; $534.3 ; 449.3 ; 424.3 ; 350.2 ; 296.2 ; 239.1 ; 154.1 . \mathrm{MS} / \mathrm{MS}$ of 689.6 (cone Voltage: $20 \mathrm{~V}$; collision energy: $45 \mathrm{~V}$ ): 689.5 ; $671.5 ; 565.4 ; 464.3 ; 369.3 ; 367.2 ; 339.2 ; 254.1 ; 197.1$; $169.1 ; 125.1$. UV $\lambda_{\max }^{\mathrm{H}_{2} \mathrm{O} / \mathrm{MeOH} 95: 5} \mathrm{~nm}(\varepsilon)<200(52,000)$. $[\alpha \mathrm{D}]_{\mathrm{D}}^{25}+0.3(c 0.1, \mathrm{MeOH})$.

\section{Neoefrapeptin $\mathrm{N}$}

HPLC Rt: 5.2 minutes HR-MS (cone Voltage: $20 \mathrm{~V}$ ) Found: 675.4930 Calcd for $\mathrm{C}_{35} \mathrm{H}_{63} \mathrm{~N}_{8} \mathrm{O}_{5}: 675.4921$ Found: $802.5237(\mathrm{M}+\mathrm{H})^{2+}$ Calcd for $\mathrm{C}_{80} \mathrm{H}_{136} \mathrm{~N}_{18} \mathrm{O}_{16}: 802.5191$; Found: 929.5457 Calcd for $\mathrm{C}_{45} \mathrm{H}_{73} \mathrm{~N}_{10} \mathrm{O}_{11}: 929.5460$. MS/MS of 929.5 (cone Voltage: $20 \mathrm{~V}$; collision energy: 30 45 V) 929.5; 844.5; 761.5; 704.4, 691.4; 633.4; 606.4; $520.3 ; 435.3 ; 410.3$, 395.3; 350.2; 336.2, 282.2; 239.1; 154.1. MS/MS of 675.5 (cone Voltage: $20 \mathrm{~V}$; collision energy: $45 \sim 60 \mathrm{~V}$ ): $675.5 ; 657.5 ; 564.4 ; 505.4 ; 489.4$, $450.3 ; 440.3 ; 422.4$, 367.2; 355.3; 339.2; 254.2; 197.1; $169.1 ; 125.1$.

\section{3}

HPLC Rt: 9.7 minutes HR-MS (cone Voltage: $15 \mathrm{~V}$ ) Found: $1214.7264(\mathrm{M}+\mathrm{H})^{+}$Calcd for $\mathrm{C}_{58} \mathrm{H}_{96} \mathrm{~N}_{13} \mathrm{O}_{15}: 1214.7149$. MS/MS of 1214.7 (cone Voltage: $20 \mathrm{~V}$; collision energy: 20 35 V): 1054.7, 943.6, 858.5, 718.4, 705.4, 647.4,
$534.4,449.3,350.2,239,154 . \mathrm{CD} \lambda^{\mathrm{H}_{2} \mathrm{O} / \mathrm{MeOH} 95: 5} \mathrm{~nm}(\Theta)$ $225 \mathrm{sh}(-24,900), 207(-69,400)$. UV $\lambda_{\max }^{\mathrm{H}_{2} \mathrm{O} / \mathrm{MeOH} 95: 5} \mathrm{~nm}(\varepsilon)$ $<200(45,000)$.

14 (C-terminal fragment of neoefrapeptin A) HPLC Rt: 6.3 minutes HR-MS (cone Voltage: $15 \mathrm{~V}$ ) Found: $436.3593\left(\mathrm{M}^{+}\right)$Calcd for $\mathrm{C}_{24} \mathrm{H}_{46} \mathrm{~N}_{5} \mathrm{O}_{2}: 436.3652$. MS/MS of 436.3 (cone Voltage: $20 \mathrm{~V}$; collision energy: $30 \mathrm{~V}$ ): 436.3, Found: 312.2708 Calcd for $\mathrm{C}_{17} \mathrm{H}_{34} \mathrm{~N}_{3} \mathrm{O}_{2}$ : 312.2651; Found: 241.1941 Calcd for $\mathrm{C}_{13} \mathrm{H}_{25} \mathrm{~N}_{2} \mathrm{O}_{2}: 241.1916$; Found: 199.1817 Calcd for $\mathrm{C}_{11} \mathrm{H}_{23} \mathrm{~N}_{2} \mathrm{O}$ : 199.1810; Found: 185.1677 Calcd for $\mathrm{C}_{10} \mathrm{H}_{21} \mathrm{~N}_{2} \mathrm{O}$ : 185.1654; Found: 125.1122 Calcd for $\mathrm{C}_{7} \mathrm{H}_{13} \mathrm{~N}_{2}$ : 125.1079; Found: 72.0850 Calcd for $\mathrm{C}_{4} \mathrm{H}_{10} \mathrm{~N}: 72.0813 . \mathrm{MS}^{3}$ of fragment 312 (LCQ deca XP Plus; normalized collision energy $40 \%$ of $\mathrm{m} / \mathrm{z} 436$ then $30 \%$ of 312 ; isolation width 3.8 ): $241,199,185 ; \mathrm{MS}^{3}$ of fragment $241: 141,113 .{ }^{13} \mathrm{C} \mathrm{NMR}\left(\mathrm{CD}_{3} \mathrm{OD}\right) \delta$; numbering see [4]; $175.4(1 \mathrm{C}=\mathrm{O}), 54.4(1 \alpha), 44.8(1 \beta), 25.7(1 \gamma)$, 22,2 $\left(1 \delta 1^{*}\right), 23.4\left(1 \delta 2^{*}\right), 61.1(2 \alpha), 30.0(2 \beta), 8.3(2 \gamma)$, $22.7(2 \beta 1), 176.9(2 \mathrm{C}=\mathrm{O}), 46.4(1), 57.9(2), 41.4(3), 25.9$ (4), $21.7\left(5^{*}\right), 23.8\left(6^{*}\right), 45.7\left(2^{\prime *}\right), 19.9\left(3^{\prime}\right), 43.5\left(4^{\prime *}\right)$, $55.6\left(6^{\prime}\right), 19.1\left(7^{\prime}\right), 31.9\left(8^{\prime}\right), 166.2\left(8^{\prime}\right.$ a) *: assignments may be interchanged. UV $\lambda^{\mathrm{H}_{2} \mathrm{O} / \mathrm{MeOH} 95: 5} \mathrm{~nm}(\varepsilon) 220(7,290)$. $\mathrm{CD} \lambda^{\mathrm{H}_{2} \mathrm{O} / \mathrm{MeOH}} 95: 5 \mathrm{~nm}(\Theta) 220(-13,800), 189(26,600)$.

15 (Ac-Pip $^{1}$-Aib-Aib-Iva-Aib-Leu $\left.{ }^{6}\right)$

HPLC Rt: 9.6 minutes HR-MS (cone Voltage: $15 \mathrm{~V}$ ) Found: 665.4189 $(\mathrm{M}+\mathrm{H})^{+}$Calcd for $\mathrm{C}_{33} \mathrm{H}_{57} \mathrm{~N}_{6} \mathrm{O}_{8}:$ 665.4238. MS/MS of 665.4 (cone Voltage: $20 \mathrm{~V}$; collision energy: 15 V): 534.3, 512.4, 449.3, 427.3, 350.2, 296.2, 239.2, 154.1.

16 ( $\beta$-Ala-Gly-Acc-Aib-Pip-Aib-Gly-Leu-Iva- $C$-Terminus) HPLC Rt: 8.0 minutes HR-MS (cone Voltage: $15 \mathrm{~V}$ ) Found: 985.6564 $\left(\mathrm{M}^{+}\right)$Calcd for $\mathrm{C}_{49} \mathrm{H}_{85} \mathrm{~N}_{12} \mathrm{O}_{9}$ : 985.6562. MS/MS (LCQ deca XP plus) of 985.7: 968.6, 857.6, 774.6, 689.6, 671.6, 588.6, 578.5, 565.5, 408.2, 367.2.

$17\left(\beta\right.$-Ala ${ }^{7}$-Gly-Acc-Aib-Pip-Aib-Gly $\left.{ }^{13}\right)$

HPLC Rt: 4.8 minutes HR-MS (cone Voltage: $15 \mathrm{~V}$ ) Found: $568.3150(\mathrm{M}+\mathrm{H})^{+}$Calcd for $\mathrm{C}_{25} \mathrm{H}_{42} \mathrm{~N}_{7} \mathrm{O}_{8}: 568.3095$ MS/MS of 568.3 (cone Voltage: $20 \mathrm{~V}$; collision energy: $25 \mathrm{~V})$ : 493.3, 408.2, 380.2, 323.2, 297.2, 272.2, 269.2, 212.1.

18

HPLC Rt: 9.9 minutes MS: $679.4(\mathrm{M}+\mathrm{H})^{+}$. MS/MS of 679.4 (cone Voltage: 20 V; collision energy: 20 V): 548.3, 526.4, 449.3, 441.3, 350.2, 310.2, 239.2, 154.1 .

19

HPLC Rt: 5.1 minutes MS: $582.3(\mathrm{M}+\mathrm{H})^{+} . \mathrm{MS} / \mathrm{MS}$ of 
582.3 (cone Voltage: $20 \mathrm{~V}$; collision energy: $25 \mathrm{~V}$ ): 507.3, 422.2, 408.3, 394.4, 323.2, 311.2, 283.2, 272.2, 212.1.

$20\left(\beta\right.$-Ala ${ }^{7}$-Gly-Acc-Aib-3-Me-Pro-Aib-Gly $\left.{ }^{13}\right)$ HPLC Rt: 5.0 minutes HR-MS (cone Voltage: $19 \mathrm{~V}$ ) Found: $568.3107(\mathrm{M}+\mathrm{H})^{+}$Calcd for $\mathrm{C}_{25} \mathrm{H}_{42} \mathrm{~N}_{7} \mathrm{O}_{8}: 568.3095$. MS/MS of 568.2 (LCQ deca XP plus): 493.2, 465.3, 408.2, 297.1, 272.1, 212.1.

\section{1}

HPLC Rt: 5.3 minutes MS: $582.3(\mathrm{M}+\mathrm{H})^{+}$. MS/MS of 582.3 (cone Voltage: $20 \mathrm{~V}$; collision energy: $25 \mathrm{~V}$ ): 507.3, 422.2, 408.3, 323.2, 311.2, 283.2, 272.2, 212.1.

22 (Ac-Pip-Aib-Pip-Iva-Aib-Leu- $\beta$-Ala-Gly-Acc-AibMePro-Aib-Gly-OH)

HPLC Rt: 9.8 minutes HR-MS (cone Voltage: $19 \mathrm{~V}$ ) Found: $607.8569(\mathrm{M}+2 \mathrm{H})^{2+}$ Calcd for $\mathrm{C}_{58} \mathrm{H}_{97} \mathrm{~N}_{13} \mathrm{O}_{15}: 607.8614$. MS/MS (LCQ deca XP plus) of $1236.8(\mathrm{M}+\mathrm{Na})^{+}: 1161.7$, 1133.8, 1076.6, 998.7, 965.7, 937.7, 897.7, 880.7, 852.6.

23 ( $\beta$-Ala-Gly-Acc-Aib-MePro-Aib-Gly-Leu-IvaC-Terminus)

HPLC Rt: 8.5 minutes HR-MS (cone Voltage: $19 \mathrm{~V}$ ) Found: 985.6555 $\left(\mathrm{M}^{+}\right)$Calcd for $\mathrm{C}_{49} \mathrm{H}_{85} \mathrm{~N}_{12} \mathrm{O}_{9}$ : 985.6562. MS/MS (LCQ deca XP plus) of 985.7: 967.8, 857.7, 774.6, 689.6, 671.6, 578.4, 565.4, 493.3, 465.5, 367.2, 339.2.

Acknowledgments We are indebted to Markus Müller, Patrick Koller, Johann Drapel and Matthias Ulrich for skilled technical assistance. Thanks are also due to Dr. Leonhard Hagmann and Dr. Tammo Winkler for NMR spectra, to Albert Pfleiderer and Dr. Joachim Blanz for recording of the QTOF data, to Dr. Erika Schmidt, Solvias AG, for CD measurements and to Dr. Andreas Stämpfli for initial work on the efrapeptins. We would also like to thank Dr. Elke Schmidt and Dr. Ernst Gassmann for their encouragements of this work.

\section{References}

1. Molleyres LP, Fredenhagen A, Schüz T, Böhlendorf B, Neff S, Huang Y. Production of neoefrapeptins for use as insecticides. (Syngenta) DE 10361201 A1, June 3 (2004)

2. Jackson CG, Linnett PE, Beechey RB, Henderson PJF. Purification and preliminary structure analysis of the efrapeptins, a group of antibiotics that inhibit the mitochondrial adenosine triphosphatase. Biochem Soc Trans 7: 224-226 (1979)

3. Bandani AR, Khambay BPS, Faull JL, Newton R, Deadman M, Butt TM. Production of efrapeptins by Tolypocladium species and evaluation of their insecticidal and antimicrobial properties. Mycological Research 104: 537-544 (2000)

4. Gupta S, Krasnoff SB, Roberts DW, Renwick JAA, Brinen LS, Clardy J. Structure of efrapeptins from the fungus Tolypocladium niveum: peptide inhibitors of mitochondrial ATPase. J Org Chem 57: 2306-2313 (1992)

5. Fearnley IM., Walker JE. Analysis of hydrophobic proteins and peptides by electrospray ionization MS. Biochem Soc Trans 24: 912-917 (1996)

6. Krasnoff SB, Gupta S, St Leger RJ, Renwick JAA, Roberts DW. Antifungal and insecticidal properties of the efrapeptins: metabolites of the fungus Tolypocladium niveum. J Invertebr Pathol 58: 180-188 (1991)

7. Lardy H, Reed P, Lin CHC. Antibiotic inhibitors of mitochondrial ATP synthesis. Fed Proc Fed Am Soc Exp Biol 34: 1707-1710 (1975)

8. Cross RL, Kohlbrenner WE. The mode of inhibition of oxidative phosphorylation by efrapeptin (A23871). Evidence for an alternating site mechanism for ATP synthesis. J Biol Chem 253: 4865-4873 (1978)

9. Brueckner H., Nicholson GJ, Jung G, Kruse K, Koenig WA. Gas chromatographic determination of the configuration of isovaline in antiamebin, samarosporin (emerimicin IV), stilbellin, suzukacillins and trichotoxins. Chromatographia 13: 209-214 (1980)

10 Ueda K, Xiao JZ, Doke N, Nakatsuka S. Structure of BZRcotoxin II produced by Bipolaris zeicola race 3, the cause of leaf spot disease in corn. Tetrahedron Lett 33: 5377-5380 (1992)

11. Debernard JJ, Flamant T, Van Der Pyl D. Isolation of peptides from Streptomyces having farnesyl transferase inhibiting properties (Rhone-Poulenc Rorer S.A., Fr.): PCT Int Appl WO 9526981 A2, Oct. 12 (1995)

12. Kakeya H, Zhang HP, Kobinata K, Onose R, Onozawa C, Kudo T, Osada H. Cytotrienin A, a novel apoptosis inducer in human leukemia HL-60 cells. J Antibiot 50: 370-372 (1997)

13. Hayakawa Y, Adachi H, Kim JW, Shin-Ya K, Seto H. Adenopeptin, a new apoptosis inducer in transformed cells from Chrysosporium sp. Tetrahedron 54: 15871-15878 (1998)

14. Fredenhagen A, Molleyres LP. unpublished results

15. Storer AC, Menard R. Catalytic mechanism in papain family of cysteine peptidases. In Methods Enzymol 244 (Proteolytic Enzymes: Serine and Cysteine Peptidases Ed. Barrett AJ): 486-500 (1994)

16. Allen G. Sequencing of protein and peptides 2nd edition, pp. 94, Elsevier, Amsterdam (1989)

17. Arnon R. Papain. In Methods Enzymol 19 Ed. Perlmann G, Lorand L, pp. 226-244, Academic Press, New York (1970)

18. Slomczynska U, Zabrocki J, Kaczmarek K, Leplawy MT, Beusen DD, Marshall GR. Facilitated synthesis of peptaibols: alamethicin via enzymic segment condensation. Biopolymers 32: 1461-1470 (1992)

19. Nakamura S, Yajima T, Lin YC, Umezawa H. Isolation and characterization of bottromycins A2, B2, C2. J Antibiot Ser 
A 20: 1-5 (1967)

20. Kaneda M. Studies on bottromycins. I. Proton and carbon13 NMR assignments of bottromycin A2, the main component of the complex. J Antibiot 45: 792-796 (1992)

21. Springer JP, Cole RJ, Dorner JW, Cox RH, Richard JL, Barnes CL, Van der Helm D. Structure and conformation of roseotoxin B. J Am Chem Soc 106: 2388-2392 (1984)

22. Tsunoo A, Kamijo M, Taketomo N, Sato Y, Ajisaka K. Roseocardin, a novel cardiotonic cyclodepsipeptide from Trichothecium roseum TT103. J Antibiot 50: 1007-1013 (1997)

23. Tan LT, Cheng XC, Jensen PR, Fenical W. Scytalidamides A and B, new cytotoxic cyclic heptapeptides from a marine fungus of the genus Scytalidium. J Org Chem 68: 8767-8773 (2003)

24. Formaggio F, Crisma M, Rossi P, Scrimin P, Kaptein B, Broxterman QB, Kamphuis J, Toniolo C. The first watersoluble 3 -helical peptides. Chem Eur J 6: 4498-4504 (2000)

25. Nguyen HH, Imhof D, Kronen M, Graefe U, Reissmann S.
Circular dichroism studies of ampullosporin-A analogues. J Pept Sci 9: 714-728 (2003)

26. Huber T, Sewald N. Conformational Analyis of Efrapeptin C, J Pept Science 2004: Supplement to Volume 10, Abstracts of the 3rd international and 28th European Peptide Symposium.

27. Abrahams JP, Buchanan SK, van Raaij MJ, Fearnley IM, Leslie AGW, Walker JE. The structure of bovine $\mathrm{F}_{1}$-ATPase complexed with the peptide antibiotic efrapeptin. Proc Natl Acad Sci USA 93: 9420-9424 (1996)

28. Toniolo C, Benedetti E. The polypeptide 310 -helix. Trends Biochem Sci 16: 350-353 (1991)

29. Koenig WA. Collection of enantiomeric separation factors obtained by capillary gas chromatography on chiral stationary phases. J High Resol Chromatogr 16: 569-586 (1993)

30. Demuth W, Karlovits M, Varmuza K. Spectral similarity versus structural similarity: mass spectrometry. Anal Chim Acta 516: 75-85 (2004) 